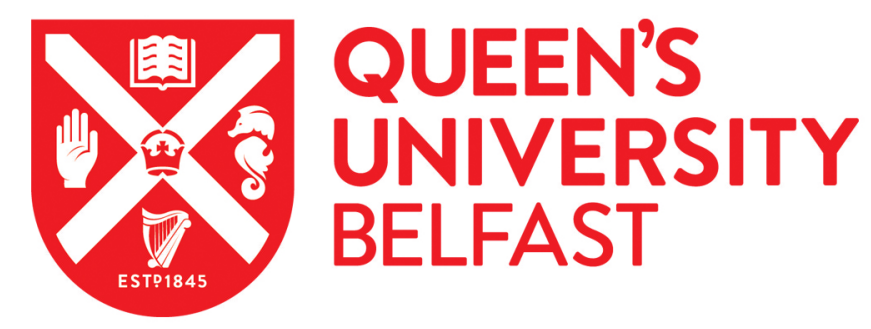

\title{
Thermophysical properties, low pressure solubilities and thermodynamics of solvation of carbon dioxide and hydrogen in two ionic liquids based on the alkylsulfate anion
}

\author{
Jacquemin, J., Husson, P., Majer, V., Padua, A. A. H., \& Costa Gomes, M. F. (2008). Thermophysical \\ properties, low pressure solubilities and thermodynamics of solvation of carbon dioxide and hydrogen in two \\ ionic liquids based on the alkylsulfate anion. Green Chemistry, 10(9), 944-950. \\ http://www.scopus.com/inward/record.url?eid=2-s2.0- \\ 50249160197\&partnerlD=40\&md5=82db74b9f527190a6a88d9ca7e5bd6a2 \\ Published in: \\ Green Chemistry
}

Document Version:

Early version, also known as pre-print

Queen's University Belfast - Research Portal:

Link to publication record in Queen's University Belfast Research Portal

\footnotetext{
General rights

Copyright for the publications made accessible via the Queen's University Belfast Research Portal is retained by the author(s) and / or other copyright owners and it is a condition of accessing these publications that users recognise and abide by the legal requirements associated with these rights.
}

Take down policy

The Research Portal is Queen's institutional repository that provides access to Queen's research output. Every effort has been made to ensure that content in the Research Portal does not infringe any person's rights, or applicable UK laws. If you discover content in the Research Portal that you believe breaches copyright or violates any law, please contact openaccess@qub.ac.uk. 


\title{
Thermophysical properties, low pressure solubilities and thermodynamics of solvation of carbon dioxide and hydrogen in two ionic liquids based on the alkylsulfate anion
}

\author{
Johan Jacquemin, Pascale Husson, Vladimir Majer, Agilio A.H. Padua and Margarida F. Costa Gomes* \\ Received 18th February 2008, Accepted 24th June 2008 \\ First published as an Advance Article on the web 24th July 2008 \\ DOI: $10.1039 / \mathrm{b802761g}$
}

Densities and viscosities of the ionic liquid 1-butyl-3-methylimidazolium octylsulfate,

$\left[\mathrm{C}_{4} \mathrm{C}_{1} \mathrm{Im}\right]\left[\mathrm{C}_{8} \mathrm{SO}_{4}\right]$ were measured as a function of temperature between $313 \mathrm{~K}$ and

$395 \mathrm{~K}$. Solubilities of hydrogen and carbon dioxide were determined, between $283 \mathrm{~K}$ and $343 \mathrm{~K}$, and at pressures close to atmospheric in $\left[\mathrm{C}_{4} \mathrm{C}_{1} \mathrm{Im}\right]\left[\mathrm{C}_{8} \mathrm{SO}_{4}\right]$ and in another ionic liquid based on the alkylsulfate anion-1-ethyl-3-methylimidazolium ethylsulfate, $\left[\mathrm{C}_{2} \mathrm{C}_{1} \mathrm{Im}\right]\left[\mathrm{C}_{2} \mathrm{SO}_{4}\right]$. Density and viscosity were measured using a vibrating tube densimeter from Anton Paar and a rheometer from Rheometrics Scientific with accuracies of $10^{-3} \mathrm{~g} \mathrm{~cm}^{-3}$ and $1 \%$, respectively. Solubilities were obtained using an isochoric saturation technique and, from the variation of solubility with temperature, the partial molar thermodynamic functions of solvation, such as the standard Gibbs energy, the enthalpy, and the entropy, are calculated. The precision of the experimental data, considered as the average absolute deviation of the Henry's law constants from appropriate smoothing equations, is better than $\pm 1 \%$.

\section{Introduction}

Much of the research on ionic liquids has been centred on their use as alternative solvents associating tuneable physicalchemical properties to a so-called green character that mainly rest on their negligible vapour pressure. ${ }^{1}$ The possibility of changing the widely used volatile organic compounds by alternative solvents, like ionic liquids, implies not only the knowledge and understanding of the properties of this new family of compounds but also the search for less toxic species that are more biodegradable and obtainable from environmentally benign sources. ${ }^{1,2}$

In 2002, Wasserscheid et al. $^{3}$ have proposed the synthesis "of even 'greener"” ionic liquids for catalytic applications. These ionic liquids should combine different environmentally favourable properties, namely a low melting point, a high chemical stability in the presence of water, the possibility of being disposed by combustion without formation of $\mathrm{HF}$ or $\mathrm{HCl}$, a high temperature for thermal decomposition, a possibility of being biodegradable and being synthesized from cheap and available raw materials. Ionic liquids based on alkylsulfate anions seem to gather most of these desired properties and they are usually considered as cheaper, ${ }^{4}$ easily prepared with high purity ${ }^{4}$ and more adequate than other imidazolium-based ionic liquids in terms of chemical stability, toxicology, degradability and environmental effects. ${ }^{5-7}$

Laboratoire Thermodynamique et Interactions Moleculaires, Université Blaise Pascal Clermont-Ferrand/CNRS, 24 avenue des Landais, 63177, Aubière Cedex, France. E-mail: margarida.c.gomes@univ-bpclermont.fr; Fax: +33 473407185; Tel: +33473407205
A relatively small number of studies are available in the literature concerning the physical-chemical properties of alkylsulfatebased ionic liquids. ${ }^{8}$ Of the published studies, the large majority concern ionic liquids containing the lower homologues of alkylsulfate anions, namely methylsulfate and ethylsulfate, ${ }^{9-11}$ and their mixtures with molecular compounds like hydrocarbons ${ }^{12-14}$ and other organic compounds, ${ }^{15}$ alcohols ${ }^{16,17}$ or water. ${ }^{16,18}$ These ionic liquids, based on methylsulfate or ethylsulfate anions, are known for their sensitivity to hydrolysis, ${ }^{3}$ which is undesired for most applications. This sensibility tends to disappear with the increase of the anion alkyl-side chain, and the ionic liquid 1-butyl3-methylimidazolium octylsulfate $\left[\mathrm{C}_{4} \mathrm{C}_{1} \mathrm{Im}\right]\left[\mathrm{C}_{8} \mathrm{SO}_{4}\right]$ is described as stable in the presence of water. ${ }^{3}$ For this ionic liquid, apart from the publication where its synthesis is firstly described, ${ }^{3}$ only two studies were found which report the thermodynamic properties of the pure ionic liquid ${ }^{8}$ and of its mixtures with alcohols or hydrocarbons. ${ }^{19}$ This liquid is described as being more viscous and having a higher melting point than those with the lower-alkyl chain homologues of the anion.

In the present paper we report the density and viscosity of $\left[\mathrm{C}_{4} \mathrm{C}_{1} \mathrm{Im}\right]\left[\mathrm{C}_{8} \mathrm{SO}_{4}\right]$ as a function of temperature and at atmospheric pressure. The solubility of carbon dioxide and hydrogen as a function of temperature and at pressures close to atmospheric are also reported for $\left[\mathrm{C}_{4} \mathrm{C}_{1} \mathrm{Im}\right]\left[\mathrm{C}_{8} \mathrm{SO}_{4}\right]$ and $\left[\mathrm{C}_{2} \mathrm{C}_{1} \mathrm{Im}\right]\left[\mathrm{C}_{2} \mathrm{SO}_{4}\right]$. The data obtained are compared to those for other ionic liquids based on different anions.

\section{Results and discussion}

Density and viscosity

The density of $\left[\mathrm{C}_{4} \mathrm{C}_{1} \mathrm{Im}\right]\left[\mathrm{C}_{8} \mathrm{SO}_{4}\right]$ was measured at atmospheric pressure and as a function of temperature from $313 \mathrm{~K}$ to 
Table 1 Experimental values of the density of $\left[\mathrm{C}_{4} \mathrm{C}_{1} \mathrm{Im}\right]\left[\mathrm{C}_{8} \mathrm{SO}_{4}\right]$ between (313 and 343) K. The percent deviations are relative to the fit of the data by eqn (1)

\begin{tabular}{lcc}
\hline$T / \mathrm{K}$ & $\rho / \mathrm{kg} \mathrm{m}^{-3}$ & $\mathrm{Dev} \%$ \\
\hline$\left[\mathrm{C}_{4} \mathrm{C}_{1} \mathrm{Im}\right]\left[\mathrm{C}_{8} \mathrm{SO}_{4}\right]$ & & \\
313.14 & 1058.0 & -0.003 \\
313.28 & 1057.8 & +0.001 \\
318.52 & 1054.5 & +0.000 \\
323.10 & 1051.5 & +0.004 \\
323.40 & 1051.4 & -0.001 \\
328.18 & 1048.3 & -0.002 \\
333.04 & 1045.3 & -0.004 \\
333.15 & 1045.0 & +0.012 \\
338.14 & 1042.1 & -0.009 \\
343.05 & 1038.9 & -0.004 \\
343.27 & 1038.6 & +0.007 \\
\hline
\end{tabular}

$343 \mathrm{~K}$. The melting point of $\left[\mathrm{C}_{4} \mathrm{C}_{1} \mathrm{Im}\right]\left[\mathrm{C}_{8} \mathrm{SO}_{4}\right]$ has been reported as being $34-35^{\circ} \mathrm{C}^{3}$ but we have observed that this salt remains as a subcooled melt for several months at room temperature (around $20^{\circ} \mathrm{C}$ ). This behaviour has been reported by other authors that were able to measure the thermodynamic properties of the subcooled liquid. ${ }^{3,8}$ We have decided to measure the liquid density of $\left[\mathrm{C}_{4} \mathrm{C}_{1} \mathrm{Im}\right]\left[\mathrm{C}_{8} \mathrm{SO}_{4}\right]$ from $313 \mathrm{~K}$, above its melting point temperature. The measured densities are listed in Table 1. The experimental values were correlated as a function of temperature following the equation:

$$
\rho\left(\mathrm{kg} \mathrm{m}^{-3}\right)=1257.9-6386.3 \times 10^{-4}(T / K)
$$

The average absolute deviation of the fit is of $0.005 \%$.

The density values obtained in this work are slightly higher than those measured by other authors. We can compare the present value at $25^{\circ} \mathrm{C}$ (by extrapolating the present results) $1067.5 \mathrm{~kg} \mathrm{~m}^{-3}$ - with the ones published by Wasserscheid et $\mathrm{al}^{3}{ }^{3}$ measured with a pycnometer-1060.1 $\mathrm{kg} \mathrm{m}^{-3}$-and by Davila et $a .^{8}{ }^{8}$ obtained with a vibrating tube densimeter- $1066.8 \mathrm{~kg}$ $\mathrm{m}^{-3}$. The present values are $0.7 \%$ higher than the pycnometric values and less than $0.1 \%$ above those recently published by Davila et al. ${ }^{8}$

Compared with other ionic liquids, based on the 1-butyl3-methylimidazolium cation, with the tetrafluoroborate, hexafluorophosphate, triflate or bis(trifluoromethanesulfonyl)imide anion, the $\left[\mathrm{C}_{4} \mathrm{C}_{1} \mathrm{Im}\right]\left[\mathrm{C}_{8} \mathrm{SO}_{4}\right]$ has a much lower density, as seen in Fig. 1, which is closer to that of classical organic solvents. It is also noteworthy that $\left[\mathrm{C}_{2} \mathrm{C}_{1} \mathrm{Im}\right]\left[\mathrm{C}_{2} \mathrm{SO}_{4}\right]^{9}$ is significantly denser than the $\left[\mathrm{C}_{4} \mathrm{C}_{1} \mathrm{Im}\right]\left[\mathrm{C}_{8} \mathrm{SO}_{4}\right]$ studied here. This observation confirms the fact that ions with longer alkyl chains lead to less dense ionic liquids. This effect was observed before for the cation's alkyl chain' and is also seen here for the anion.

The dynamic viscosity was measured for $\left[\mathrm{C}_{4} \mathrm{C}_{1} \mathrm{Im}\right]\left[\mathrm{C}_{8} \mathrm{SO}_{4}\right]$, previously dried, and is listed in Table 2 as a function of temperature from (314 to 395) K. It was first observed that the viscosity of the sample remained constant with increasing shear rates (from 0 to $500 \mathrm{~s}^{-1}$ ). This linear relationship between the shear stress and the shear rate corresponds to a Newtonian behaviour that has been also reported by Wasserscheid et al. ${ }^{3}$ for $\left[\mathrm{C}_{4} \mathrm{C}_{1} \mathrm{Im}\right]\left[\mathrm{C}_{8} \mathrm{SO}_{4}\right]$.

In the temperature range studied, the viscosity drastically decreases with increasing temperature. This variation is very important for $\left[\mathrm{C}_{4} \mathrm{C}_{1} \mathrm{Im}\right]\left[\mathrm{C}_{8} \mathrm{SO}_{4}\right]$ which is 19 times more viscous

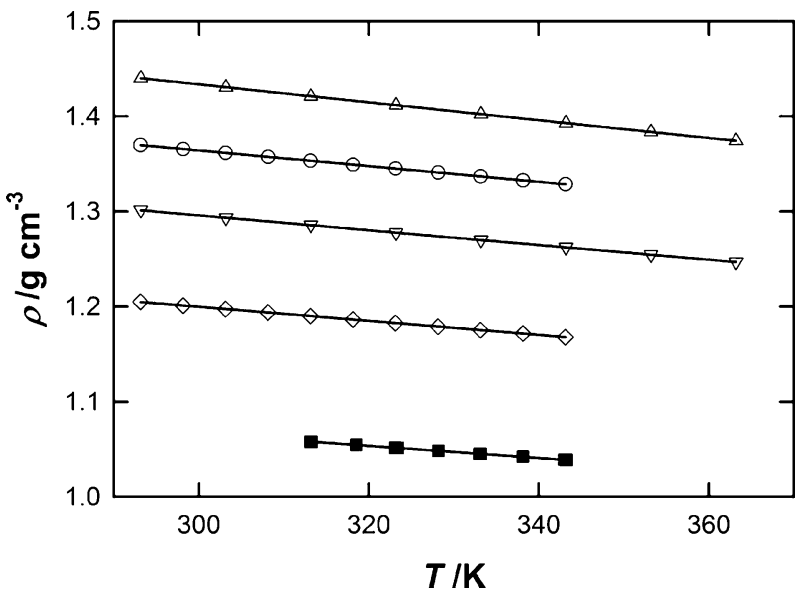

Fig. 1 Experimental density of $\left[\mathrm{C}_{4} \mathrm{C}_{1} \mathrm{Im}\right]\left[\mathrm{C}_{8} \mathrm{SO}_{4}\right]$ : ( $\mathbf{\square}$ ), as a function of the temperature. Comparison of this density with other $\left[\mathrm{C}_{4} \mathrm{C}_{1} \mathrm{Im}\right]$ based ionic liquids: ${ }^{38}(\triangle),\left[\mathrm{C}_{4} \mathrm{C}_{1} \operatorname{Im}\right]\left[\mathrm{NTf}_{2}\right] ;(\bigcirc),\left[\mathrm{C}_{4} \mathrm{C}_{1} \mathrm{Im}\right]\left[\mathrm{PF}_{6}\right] ;(\nabla)$, $\left[\mathrm{C}_{4} \mathrm{C}_{1} \mathrm{In}\right][\mathrm{OTf}] ;(\diamond),\left[\mathrm{C}_{4} \mathrm{C}_{1} \mathrm{Im}\right]\left[\mathrm{BF}_{4}\right]$; as a function of temperature. The lines correspond to the linear fit of the data as a function of temperature.

Table 2 Experimental values of the viscosity of $\left[\mathrm{C}_{4} \mathrm{C}_{1} \mathrm{Im}\right]\left[\mathrm{C}_{8} \mathrm{SO}_{4}\right]$ between (314 and 395) $\mathrm{K}$ and of $\left[\mathrm{C}_{4} \mathrm{C}_{1} \mathrm{Im}\right]\left[\mathrm{C}_{8} \mathrm{SO}_{4}\right]$. The percent deviations are relative to the fit of the data by eqn (2)

\begin{tabular}{lcc}
\hline$T / \mathrm{K}$ & $\eta / \mathrm{mPa}$ & $\mathrm{Dev} \%$ \\
\hline$\left[\mathrm{C}_{4} \mathrm{C}_{1} \mathrm{Im}\right]\left[\mathrm{C}_{8} \mathrm{SO}_{4}\right]$ & & \\
314.25 & 281 & -0.2 \\
323.77 & 168 & +0.0 \\
333.04 & 108 & +0.4 \\
342.07 & 74.2 & -0.0 \\
352.98 & 49.5 & -0.1 \\
362.10 & 36.6 & -0.0 \\
373.90 & 25.9 & -0.3 \\
384.11 & 19.8 & -0.2 \\
395.32 & 15.1 & +0.4 \\
\hline
\end{tabular}

at $313 \mathrm{~K}$ than at $395 \mathrm{~K}$. In Fig. 2, the viscosity of several ionic liquids, measured before in the same temperature range, ${ }^{9}$ is represented together with the values obtained in this work. The $\left[\mathrm{C}_{4} \mathrm{C}_{1} \mathrm{Im}\right]\left[\mathrm{C}_{8} \mathrm{SO}_{4}\right]$ is the most viscous of the ionic liquids studied, circa two times more viscous than $\left[\mathrm{C}_{4} \mathrm{C}_{1} \mathrm{Im}\right]\left[\mathrm{PF}_{6}\right]$ at $314 \mathrm{~K}$ but having only a slightly more important viscosity at temperatures above $350 \mathrm{~K}$. The $\left[\mathrm{C}_{2} \mathrm{C}_{1} \mathrm{Im}\right]\left[\mathrm{C}_{2} \mathrm{SO}_{4}\right]$, also based in an alkylsulfate anion, has a much lower viscosity as observed in Fig. 2. At $310 \mathrm{~K}$, a large difference on the viscosities of the two liquids is observed $-59 \mathrm{mPa}$ s for $\left[\mathrm{C}_{2} \mathrm{C}_{1} \mathrm{Im}\right]\left[\mathrm{C}_{2} \mathrm{SO}_{4}\right]$ compared with $361 \mathrm{mPa}$ s for $\left[\mathrm{C}_{4} \mathrm{C}_{1} \mathrm{Im}\right]\left[\mathrm{C}_{8} \mathrm{SO}_{4}\right]$. This difference decreases with temperature and at $395 \mathrm{~K}$ a viscosity of $7 \mathrm{mPa}$ s for $\left[\mathrm{C}_{2} \mathrm{C}_{1} \mathrm{Im}\right]\left[\mathrm{C}_{2} \mathrm{SO}_{4}\right]$ has been measured, ${ }^{9}$ compared with $15 \mathrm{mPa}$ s for $\left[\mathrm{C}_{4} \mathrm{C}_{1} \mathrm{Im}\right]\left[\mathrm{C}_{8} \mathrm{SO}_{4}\right]$.

The Vogel-Fulcher-Tamman (VFT) equation is used to correlate the experimental viscosities as a function of temperature:

$$
\eta=\left(4.153 \times 10^{-3}\right) T^{0.5} \exp (1149 /(T-174.9))
$$

with an average absolute deviation of $0.3 \%$ in the present case.

\section{Gas solubility}

For each pair gas-ionic liquid studied, multiple experimental data points were obtained in the temperature interval between $283 \mathrm{~K}$ and $343 \mathrm{~K}$ in steps of approximately $10 \mathrm{~K}$. The 


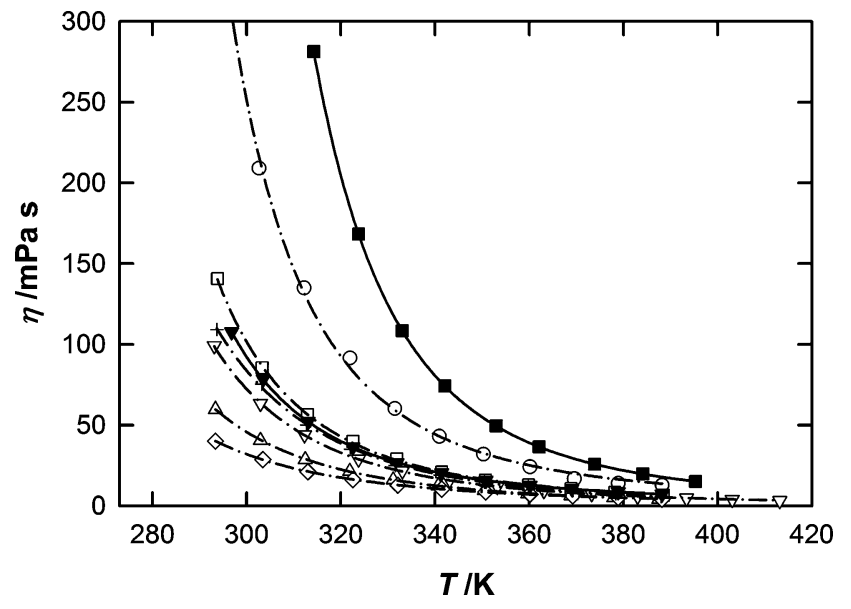

Fig. 2 Experimental viscosities as a function of temperature. (ם), $\left[\mathrm{C}_{4} \mathrm{C}_{1} \mathrm{Im}\right]\left[\mathrm{C}_{8} \mathrm{SO}_{4}\right]$, this work; ( $\left.\mathbf{\nabla}\right)$,1-ethyl-3-methylimidazolium ethylsulfate $\left[\mathrm{C}_{2} \mathrm{C}_{1} \mathrm{Im}\right]\left[\mathrm{C}_{2} \mathrm{SO}_{4}\right] ;{ }^{9}(\mathrm{O})$, 1-butyl-3-methylimidazolium hexafluorophosphate $\left[\mathrm{C}_{4} \mathrm{C}_{1} \mathrm{Im}\right]\left[\mathrm{PF}_{6}\right] ;{ }^{9} \quad(+)$, 1-methyl-3-butylimidazolium tetrafluoroborate $\left[\mathrm{C}_{4} \mathrm{C}_{1} \mathrm{Im}\right]\left[\mathrm{BF}_{4}\right]{ }^{9}(\triangle)$, 1-methyl-3-butylimidazolium bis(trifluoromethylsulfonyl)imide $\left[\mathrm{C}_{4} \mathrm{C}_{1} \operatorname{Im}\right]\left[\mathrm{NTf}_{2}\right] ;{ }^{9}(\nabla)$, Butylmethylpyrrolidinium bis(trifluoromethylsulfonyl)imide $\left[\mathrm{C}_{4} \mathrm{C}_{1}\right.$ Pyrro $]\left[\mathrm{NTf}_{2}\right]^{9}{ }^{9}$ ( $\square$ ), butyltrimethylammonium bis(trifluoromethylsulfonyl)imide $\left[\mathrm{N}_{4111}\right]\left[\mathrm{NTf}_{2}\right] ;^{9} \quad(\diamond), 1$-ethyl-3-methylimidazolium bis(trifluoromethylsulfonyl)imide $\left[\mathrm{C}_{2} \mathrm{C}_{1} \mathrm{im}\right]\left[\mathrm{NTf}_{2}\right] .^{9}$ The lines correspond to the fit of the data.

experimental gas solubilities in the two ionic liquids$\left[\mathrm{C}_{2} \mathrm{C}_{1} \mathrm{Im}\right]\left[\mathrm{C}_{2} \mathrm{SO}_{4}\right]$ and $\left[\mathrm{C}_{4} \mathrm{C}_{1} \mathrm{Im}\right]\left[\mathrm{C}_{8} \mathrm{SO}_{4}\right]$ - are reported in Tables 3 and 4 for hydrogen and carbon dioxide, respectively. The solubility results are given both as Henry's law constants and as mole fractions of solute. These latter values are calculated from the experimental data on $K_{\mathrm{H}}$ (at slightly different total pressures) assuming a partial pressure of the gaseous solute equal to $0.1 \mathrm{MPa}$. The relative atomic masses used are the ones recommended by IUPAC ${ }^{20}$ and the values of the second virial coefficients for all the gases, necessary for the calculation of the compressibility factor, were taken from the compilation by Dymond and Smith. ${ }^{21}$

To obtain representative values of the solubility, the raw experimental data were correlated as a function of temperature by an empirical equation of the type:

$$
\ln \left[K_{\mathrm{H}}(T) / 10^{5} \mathrm{~Pa}\right]=\sum_{i=0}^{n} A_{i}(T / \mathrm{K})^{-i}
$$

the optimized coefficients $A_{i}$ are listed in Table 5 together with the average absolute deviations for each solute. These values can be regarded as an estimation of the precision of the experimental data, which is in the present case always less than $1 \%$.

In Fig. 3 are represented the solubility data expressed in mole fraction, for carbon dioxide and hydrogen in the two ionic liquids as a function of temperature. As it can be observed by comparing both plots, carbon dioxide is at least one order of magnitude more soluble in both liquids than hydrogen. The solubility of both gases is higher in $\left[\mathrm{C}_{4} \mathrm{C}_{1} \mathrm{Im}\right]\left[\mathrm{C}_{8} \mathrm{SO}_{4}\right]$. As it has been observed before, ${ }^{22,23}$ the increase of the alkyl side chain in the cation causes a slight increase on the gas solubility. This effect seems to be even more pronounced in this case, where the alkyl side chain is also longer in the anion of the ionic liquid.
Table 3 Experimental values of $\mathrm{H}_{2}$ in $\left[\mathrm{C}_{2} \mathrm{C}_{1} \mathrm{Im}\right]\left[\mathrm{C}_{2} \mathrm{SO}_{4}\right]$ and $\left[\mathrm{C}_{4} \mathrm{C}_{1} \mathrm{Im}\right]\left[\mathrm{C}_{8} \mathrm{SO}_{4}\right]$ expressed both as Henry's law constants, $K_{\mathrm{H}}$ and as $\mathrm{H}_{2}$ mole fraction, $x_{2}$, corrected for a partial pressure of solute of $0.1 \mathrm{MPa}$. $p$ is the experimental equilibrium pressure and the percent deviation is relative to the correlations of the data reported in Table 5

\begin{tabular}{lrlll}
\hline$T / \mathrm{K}$ & $p / 10^{2} \mathrm{~Pa}$ & $K_{\mathrm{H}} / 10^{5} \mathrm{~Pa}$ & $x_{2} / 10^{-4}$ & $\mathrm{Dev} \%$ \\
\hline$\left[\mathrm{C}_{2} \mathrm{C}_{1} \mathrm{Im}\right]\left[\mathrm{C}_{2} \mathrm{SO}_{4}\right]$ & & & & \\
283.16 & 779.45 & 2492 & 4.015 & -0.3 \\
292.93 & 804.85 & 2143 & 4.669 & +0.1 \\
303.39 & 499.66 & 2056 & 4.866 & +0.6 \\
303.39 & 832.19 & 2062 & 4.853 & +0.3 \\
303.42 & 921.92 & 2071 & 4.831 & -0.1 \\
316.29 & 959.48 & 2280 & 4.389 & -0.4 \\
323.29 & 980.04 & 2544 & 3.933 & -1.1 \\
324.27 & 531.49 & 2516 & 3.976 & +1.7 \\
333.12 & 1008.87 & 3071 & 3.258 & -0.4 \\
333.22 & 545.39 & 3107 & 3.220 & -1.3 \\
343.13 & 937.32 & 3924 & 2.550 & +0.1 \\
343.13 & 1038.24 & 3894 & 2.569 & +0.9 \\
{$\left[\mathrm{C}_{4} \mathrm{C}_{1} \mathrm{Im}\right]\left[\mathrm{C}_{8} \mathrm{SO}_{4}\right]$} & & & & \\
313.33 & 921.66 & 1892 & 5.288 & +0.1 \\
313.33 & 832.13 & 1891 & 5.292 & -0.0 \\
323.03 & 857.54 & 2062 & 4.853 & +0.3 \\
323.20 & 950.28 & 2047 & 4.887 & -0.5 \\
332.87 & 883.34 & 2279 & 4.390 & +0.2 \\
342.69 & 909.05 & 2531 & 3.953 & -0.9 \\
342.98 & 1007.71 & 2584 & 3.873 & +0.8 \\
\hline
\end{tabular}

Table 4 Experimental values of $\mathrm{CO}_{2}$ in $\left[\mathrm{C}_{2} \mathrm{C}_{1} \mathrm{Im}\right]\left[\mathrm{C}_{2} \mathrm{SO}_{4}\right]$ and $\left[\mathrm{C}_{4} \mathrm{C}_{1} \mathrm{Im}\right]\left[\mathrm{C}_{8} \mathrm{SO}_{4}\right]$ expressed both as Henry's law constants, $K_{\mathrm{H}}$ and as $\mathrm{CO}_{2}$ mole fraction, $x_{2}$, corrected for a partial pressure of solute of $0.1 \mathrm{MPa} . p$ is the experimental equilibrium pressure and the percent deviation is relative to the correlations of the data reported in Table 5

\begin{tabular}{lcccc}
\hline$T / \mathrm{K}$ & $p / 10^{2} \mathrm{~Pa}$ & $K_{\mathrm{H}} / 10^{5} \mathrm{~Pa}$ & $x_{2} / 10^{-4}$ & $\mathrm{Dev} \%$ \\
\hline$\left[\mathrm{C}_{2} \mathrm{C}_{1} \mathrm{Im}\right]\left[\mathrm{C}_{2} \mathrm{SO}_{4}\right]$ & & & & \\
283.32 & 380.10 & 62.13 & 160.0 & -0.1 \\
293.48 & 402.72 & 77.22 & 128.8 & +0.2 \\
303.38 & 836.77 & 94.28 & 105.6 & +0.1 \\
303.39 & 777.62 & 94.52 & 105.3 & -0.1 \\
313.28 & 869.49 & 113.2 & 88.00 & +0.4 \\
313.28 & 443.24 & 114.1 & 87.30 & -0.4 \\
314.68 & 813.40 & 117.0 & 85.15 & -0.4 \\
323.18 & 901.28 & 134.2 & 74.22 & +0.6 \\
323.24 & 839.67 & 135.7 & 73.41 & -0.4 \\
333.12 & 932.51 & 158.1 & 63.02 & +0.5 \\
333.14 & 869.20 & 159.0 & 62.68 & -0.0 \\
333.16 & 479.90 & 159.5 & 62.48 & -0.3 \\
343.08 & 898.46 & 186.0 & 53.58 & -0.4 \\
343.12 & 963.32 & 184.7 & 53.96 & +0.3 \\
{$\left[\mathrm{C}_{4} \mathrm{C}_{1} \mathrm{Im}\right]\left[\mathrm{C}_{8} \mathrm{SO}_{4}\right]$} & & & & \\
313.15 & 682.01 & 64.84 & 153.6 & +0.9 \\
313.33 & 702.76 & 63.71 & 156.3 & -1.0 \\
322.31 & 725.63 & 70.81 & 140.7 & -1.1 \\
322.81 & 705.87 & 73.09 & 136.3 & +1.5 \\
332.27 & 728.35 & 80.51 & 123.8 & -1.1 \\
332.28 & 752.10 & 81.89 & 121.7 & +0.6 \\
342.23 & 778.22 & 94.57 & 105.4 & +1.1 \\
343.22 & 755.86 & 94.03 & 106.0 & -0.9 \\
\hline & & & &
\end{tabular}

The behaviour of $\left[\mathrm{C}_{4} \mathrm{C}_{1} \mathrm{Im}\right]\left[\mathrm{C}_{8} \mathrm{SO}_{4}\right]$ is compared, in Fig. 4, with that of other ionic liquids sharing the same cation, 1-butyl-3-methylimidazolium, but with different anionstetrafluoroborate, ${ }^{24}$ hexafluorophosphate ${ }^{25}$ and bis(trifluoromethylsulfonyl)imide. ${ }^{23} \mathrm{It}$ is observed that both gases are approximately twice more soluble in $\left[\mathrm{C}_{4} \mathrm{C}_{1} \mathrm{Im}\right]\left[\mathrm{NTf}_{2}\right]$ than in the three other ionic liquids. The solubility of carbon dioxide or of hydrogen is similar in $\left[\mathrm{C}_{4} \mathrm{C}_{1} \mathrm{Im}\right]\left[\mathrm{C}_{8} \mathrm{SO}_{4}\right]$ and in $\left[\mathrm{C}_{4} \mathrm{C}_{1} \mathrm{Im}\right]\left[\mathrm{PF}_{6}\right]$, 
Table 5 Parameters of eqn (3) used to smooth the experimental results on $K_{\mathrm{H}}$ from Table 3 and Table 4 along with the percent average absolute deviation of the fit (AAD)

\begin{tabular}{lclll}
\hline Gas & $A_{0}$ & $A_{1}$ & $A_{2}$ & $\mathrm{AAD} \%$ \\
\hline$\left[\mathrm{C}_{2} \mathrm{C}_{1} \mathrm{Im}\right]\left[\mathrm{C}_{2} \mathrm{SO}_{4}\right]$ & & & & \\
$\mathrm{H}_{2}$ & +51.46 & $-2.644 \times 10^{4}$ & $+3.986 \times 10^{6}$ & 0.6 \\
$\mathrm{CO}_{2}$ & +9.967 & $-1.505 \times 10^{3}$ & $-4.229 \times 10^{4}$ & 0.3 \\
{$\left[\mathrm{C}_{4} \mathrm{C}_{1} \mathrm{Im}\right]\left[\mathrm{C}_{8} \mathrm{SO}_{4}\right]$} & & & & \\
$\mathrm{H}_{2}$ & +23.28 & $-9.121 \times 10^{3}$ & $+1.313 \times 10^{6}$ & 0.4 \\
$\mathrm{CO}_{2}$ & +18.61 & $-7.959 \times 10^{3}$ & $+1.075 \times 10^{6}$ & 1.0 \\
\hline
\end{tabular}
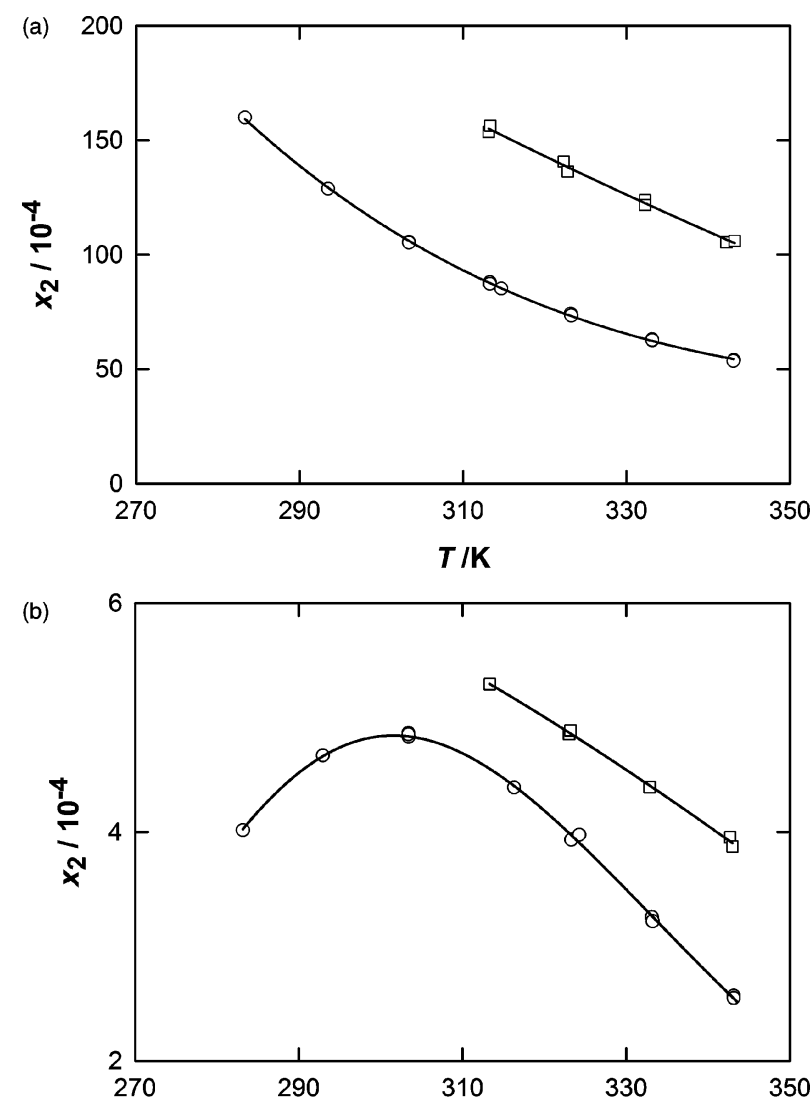

Fig. 3 Mole fraction gas solubilities of $\mathrm{CO}_{2}$ (upper plot) and $\mathrm{H}_{2}$ (lower plot) at $0.1 \mathrm{MPa}$ partial pressure of the solute and as a function of temperature in: $\mathrm{O},\left[\mathrm{C}_{2} \mathrm{C}_{1} \mathrm{Im}\right]\left[\mathrm{C}_{2} \mathrm{SO}_{4}\right] ; \square,\left[\mathrm{C}_{4} \mathrm{C}_{1} \mathrm{Im}\right]\left[\mathrm{C}_{8} \mathrm{SO}_{4}\right]$. Lines represent the smoothed data.

in spite of the quite different molecular structure of the anions. The lowest solubility is observed for the two gases for $\left[\mathrm{C}_{4} \mathrm{C}_{1} \mathrm{Im}\right]\left[\mathrm{BF}_{4}\right]$. The solubility of hydrogen in $\left[\mathrm{C}_{2} \mathrm{C}_{1} \mathrm{Im}\right]\left[\mathrm{C}_{2} \mathrm{SO}_{4}\right]$ has a peculiar bahaviour with temperature as it was previously found in other ionic liquids like, for example, $\left[\mathrm{C}_{4} \mathrm{C}_{1} \mathrm{Im}\right]\left[\mathrm{BF}_{4}\right]^{24}$ or $\left[\mathrm{C}_{4} \mathrm{C}_{1} \mathrm{Im}\right]\left[\mathrm{PF}_{6}\right]^{25,26}$ where the solubility is not monotonous in the temperature range studied ${ }^{24,25}$ or slightly increases with temperature. $^{26}$

The variation with temperature of gas solubility, expressed as Henry's law constant, is directly related to the thermodynamic properties of solvation which, in the case of gaseous solutes at low pressures, is practically identical to the thermodynamic properties of solution. ${ }^{27}$ The Gibbs energy of solvation, corresponding to the change in Gibbs energy when the solute is transferred, at constant temperature, from the pure, perfect gas
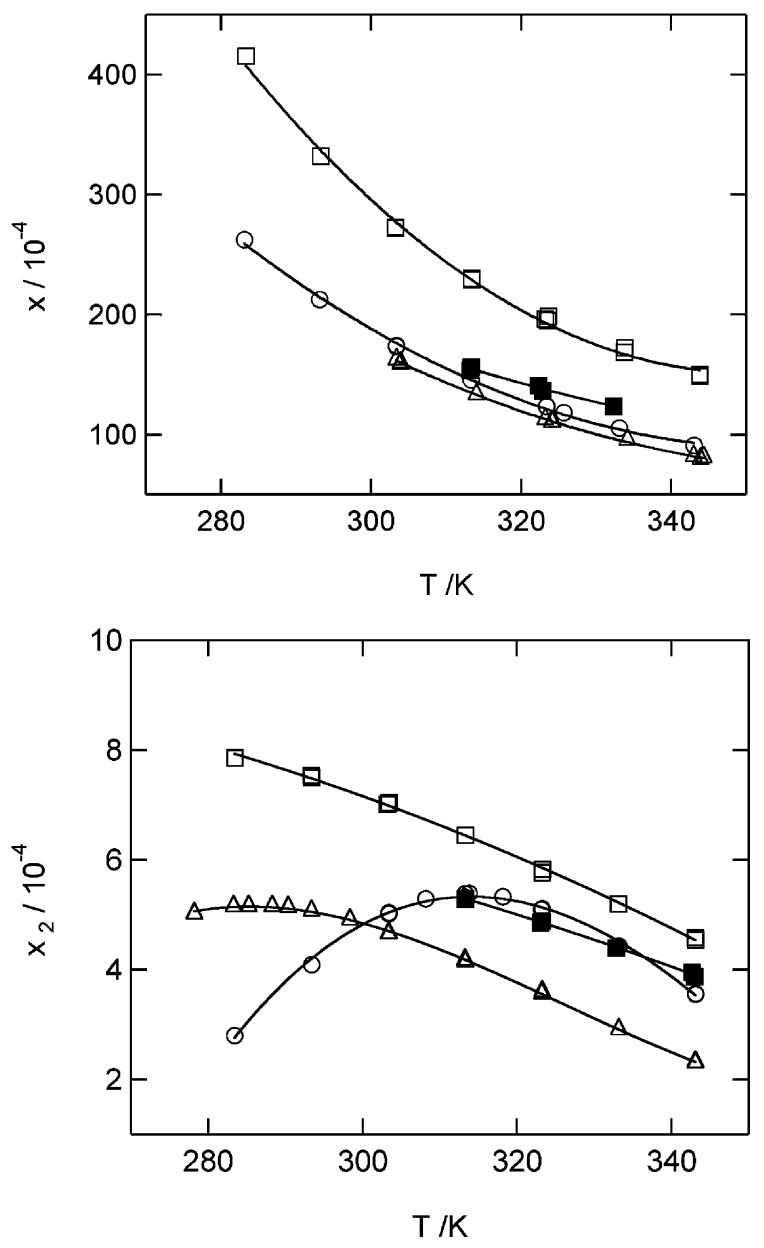

Fig. 4 Mole fraction gas solubilities of $\mathrm{CO}_{2}$ (upper plot) and of $\mathrm{H}_{2}$ (lower plot) in several ionic liquids based on the $\left[\mathrm{C}_{4} \mathrm{C}_{1} \mathrm{Im}\right]$ cation: $\mathrm{O},\left[\mathrm{C}_{4} \mathrm{C}_{1} \operatorname{Im}\right]\left[\mathrm{PF}_{6}\right] ;{ }^{25} \square,\left[\mathrm{C}_{4} \mathrm{C}_{1} \mathrm{Im}\right]\left[\mathrm{Ntf}_{2}\right], 22 \Delta,\left[\mathrm{C}_{4} \mathrm{C}_{1} \operatorname{Im}\right]\left[\mathrm{BF}_{4}\right] ;{ }^{24}$ $\left[\mathrm{C}_{4} \mathrm{C}_{1} \mathrm{Im}\right]\left[\mathrm{C}_{8} \mathrm{SO}_{4}\right]$, this work.

state at the standard pressure to the standard state of infinite dilution in the solvent, is given by

$$
\Delta_{\text {solv }} G=R T \ln \left(K_{\mathrm{H}} / p^{0}\right)
$$

where $p^{0}$ is the standard-state pressure. The partial molar differences in enthalpy and entropy between the two states can be obtained by calculating the corresponding partial derivatives of the Gibbs energy with respect to temperature

$$
\begin{gathered}
\Delta_{\text {solv }} H=-T^{2} \partial / \partial T\left(\Delta_{\text {solv }} G / T\right)=-R T^{2} \partial / \partial T\left[\ln \left(K_{\mathrm{H}} / p^{0}\right)\right] \\
\begin{aligned}
\Delta_{\text {solv }} S & =\left(\Delta_{\text {solv }} H-\Delta_{\text {solv }} G\right) / T \\
& =-R T \partial / \partial T\left[\ln \left(K_{\mathrm{H}} / p^{0}\right)\right]-R \ln \left(K_{\mathrm{H}} / p^{0}\right)
\end{aligned}
\end{gathered}
$$

The values for the Gibbs energy, enthalpy and entropy of solvation are given in Table 6 for the two gases in the two ionic liquids at several discrete temperatures between $283 \mathrm{~K}$ and $343 \mathrm{~K}$.

The analysis of the thermodynamic properties of solvation allows the interpretation of the values of gas solubility encountered. It is observed that, in the case of hydrogen, the higher solubility measured in $\left[\mathrm{C}_{4} \mathrm{C}_{1} \mathrm{Im}\right]\left[\mathrm{C}_{8} \mathrm{SO}_{4}\right]$ corresponds both to a more favorable enthalpic term (the enthalpy of solvation is more negative for this ionic liquid) and a more favorable entropic term 
Table 6 Thermodynamic functions of solvation for $\mathrm{H}_{2}$ and $\mathrm{CO}_{2}$ in $\left[\mathrm{C}_{2} \mathrm{C}_{1} \mathrm{Im}\right]\left[\mathrm{C}_{2} \mathrm{SO}_{4}\right]$ and $\left[\mathrm{C}_{4} \mathrm{C}_{1} \mathrm{Im}\right]\left[\mathrm{C}_{8} \mathrm{SO}_{4}\right]$ at several discrete temperatures between $283 \mathrm{~K}$ and $343 \mathrm{~K} . \Delta_{\text {solv }} G$ is the Gibbs energy of solvation, $\Delta_{\text {solv }} H$ the enthalpy of solvation and $\Delta_{\text {solv }} S$ the entropy of solvation. The values are consistent with $p^{0}=0.1 \mathrm{MPa}$

\begin{tabular}{|c|c|c|c|}
\hline$T / \mathrm{K}$ & $\begin{array}{l}\Delta_{\text {solv }} G / \\
\mathrm{kJ} \mathrm{mol}^{-1}\end{array}$ & $\begin{array}{l}\Delta_{\text {solv }} H / \\
\mathrm{kJ} \mathrm{mol}^{-1}\end{array}$ & $\begin{array}{l}\Delta_{\text {solv }} S / \\
\mathrm{J} \mathrm{mol}^{-1} \mathrm{~K}^{-1}\end{array}$ \\
\hline \multicolumn{4}{|l|}{$\left[\mathrm{C}_{2} \mathrm{C}_{1} \mathrm{Im}\right]\left[\mathrm{C}_{2} \mathrm{SO}_{4}\right]+\mathrm{H}_{2}$} \\
\hline 283 & 18.40 & +14.4 & -14.1 \\
\hline 293 & 18.69 & +6.43 & -41.8 \\
\hline 303 & 19.23 & -1.04 & -66.9 \\
\hline 313 & 20.02 & -8.03 & -89.6 \\
\hline 323 & 21.02 & -14.6 & -110 \\
\hline 333 & 22.21 & -20.7 & -129 \\
\hline 343 & 23.59 & -26.6 & -146 \\
\hline \multicolumn{4}{|l|}{$\left[\mathrm{C}_{4} \mathrm{C}_{1} \mathrm{Im}\right]\left[\mathrm{C}_{8} \mathrm{SO}_{4}\right]+\mathrm{H}_{2}$} \\
\hline 313 & 19.63 & -6.08 & -82.1 \\
\hline 323 & 20.48 & -8.24 & -88.9 \\
\hline 333 & 21.41 & -10.3 & -95.1 \\
\hline 343 & 22.38 & -12.2 & -101 \\
\hline \multicolumn{4}{|l|}{$\left[\mathrm{C}_{2} \mathrm{C}_{1} \mathrm{Im}\right]\left[\mathrm{C}_{2} \mathrm{SO}_{4}\right]+\mathrm{CO}_{2}$} \\
\hline 283 & 9.698 & -15.0 & -87.3 \\
\hline 293 & 10.57 & -14.9 & -87.0 \\
\hline 303 & 11.44 & -14.8 & -86.7 \\
\hline 313 & 12.30 & -14.8 & -86.5 \\
\hline 323 & 13.17 & -14.7 & -86.2 \\
\hline 333 & 14.03 & -14.6 & -86.0 \\
\hline 343 & 14.89 & -14.6 & -85.9 \\
\hline \multicolumn{4}{|l|}{$\left[\mathrm{C}_{4} \mathrm{C}_{1} \mathrm{Im}\right]\left[\mathrm{C}_{8} \mathrm{SO}_{4}\right]+\mathrm{CO}_{2}$} \\
\hline 313 & 10.83 & -9.05 & -63.5 \\
\hline 323 & 11.49 & -10.8 & -69.1 \\
\hline 333 & 12.21 & -12.5 & -74.1 \\
\hline 343 & 12.97 & -14.0 & -78.8 \\
\hline
\end{tabular}

(the entropy of solvation is less negative). For the solubility of carbon dioxide, it is the entropic term that causes a higher solubility as, in this case, a less negative entropy of solvation explains the experimental result obtained for the gas solubility.

For the case of hydrogen, the thermodynamic properties of solvation reflect the variation of the solubility with temperature. In the lower temperature end, the enthalpy of solvation for hydrogen in $\left[\mathrm{C}_{2} \mathrm{C}_{1} \mathrm{Im}\right]\left[\mathrm{C}_{2} \mathrm{SO}_{4}\right]$ is slightly positive which means that the solvation process is endothermic in these temperatures. This result has been found for the solubility of hydrogen in other ionic liquids, for example, in $\left[\mathrm{C}_{4} \mathrm{C}_{1} \mathrm{Im}\right]\left[\mathrm{BF}_{4}\right],{ }^{24}$ in $\left[\mathrm{C}_{4} \mathrm{C}_{1} \mathrm{Im}\right]\left[\mathrm{PF}_{6}\right]^{25}$ and $\left[\mathrm{N}_{4111}\right]\left[\mathrm{NTf}_{2}\right]^{23}$ previously measured by the authors of the present work and in $\left[\mathrm{C}_{4} \mathrm{C}_{1} \mathrm{Im}\right]\left[\mathrm{C}_{1} \mathrm{SO}_{4}\right],{ }^{28}\left[\mathrm{C}_{4} \mathrm{C}_{1} \mathrm{Im}\right]\left[\mathrm{PF}_{6}\right]^{26}$ and $\left[\mathrm{C}_{6} \mathrm{C}_{1} \mathrm{Im}\right]\left[\mathrm{NTf}_{2}\right]^{29}$ formerly published by Kumelan et al.

\section{Experimental}

\section{Samples}

The samples of the alkylsulfate-based ionic liquids (minimum stated purity of 0.99 in mole fraction, as obtained by ${ }^{1} \mathrm{H}-\mathrm{NMR}$ analysis) were supplied by the group of Prof. Wasserscheid at the University of Erlangen-Nürnberg, Germany.

1-Butyl-3-methylimidazolium octylsulfate, $\left[\mathrm{C}_{4} \mathrm{C}_{1} \mathrm{Im}\right]\left[\mathrm{C}_{8} \mathrm{SO}_{4}\right]-$ CAS registry number 445473-58-5-was prepared via a metathesis reaction between 3-butyl-1-methylimidazolium chloride and sodium sulfate, according to the reported procedures by Wasserscheid et al. ${ }^{3}$ 1-Ethyl-3-methylimidazolium ethyl sulfate, $\left[\mathrm{C}_{2} \mathrm{C}_{1} \mathrm{Im}\right]\left[\mathrm{C}_{2} \mathrm{SO}_{4}\right]-\mathrm{CAS}$ registry number 342573-75-5-was prepared by reaction of 1-methylimidazole with diethyl sulfate according to the reported procedures by $\mathrm{Xu}$ et al. ${ }^{30}$

Before starting each measurement, the ionic liquids were kept under vacuum (pressure lower than $1 \mathrm{~Pa}$ ) for at least $15 \mathrm{~h}$ at $323 \mathrm{~K}$. Before being introduced to each apparatus, the samples were kept under nitrogen at 1 bar. This inert gas was chosen because of its very low solubility in the ionic liquids. ${ }^{24}$ To avoid any contact of the sample with atmosphere, a septum adapted to the storage Schlenk flask and a syringe equipped with a Luer-lock valve were used to load the samples into the different instruments.

The water content was determined for each sample of ionic liquid before and after each series of measurements using a volumetric Karl Fisher titration method (Mettler Toledo DL31). No variation of the water content was found in the samples of ionic liquid used. For $\left[\mathrm{C}_{2} \mathrm{C}_{1} \mathrm{Im}\right]\left[\mathrm{C}_{2} \mathrm{SO}_{4}\right]$, the water quantities measured were $(100 \pm 10) \mathrm{ppm}$ and for $\left[\mathrm{C}_{4} \mathrm{C}_{1} \mathrm{Im}\right]\left[\mathrm{C}_{8} \mathrm{SO}_{4}\right]$ they were $(200 \pm 10)$ ppm.

The halide content of the two ionic liquids was determined using suppressed ion chromatography (IC). ${ }^{31} \mathrm{The}\left[\mathrm{C}_{2} \mathrm{C}_{1} \mathrm{Im}\right]\left[\mathrm{C}_{2} \mathrm{SO}_{4}\right]$ is an halogen-free ionic liquid. The sample of $\left[\mathrm{C}_{4} \mathrm{C}_{1} \mathrm{Im}\right]\left[\mathrm{C}_{8} \mathrm{SO}_{4}\right]$ used contains less than $10 \mathrm{ppm}$ of chloride.

Carbon dioxide and hydrogen used for this study come from to AGA/Linde Gaz with mole fraction purities of 0.99995 and 0.9998, respectively. All gases were used as received from the manufacturer.

\section{Density}

Densities were measured using a U-shape vibrating-tube densimeter (Anton Paar, model DMA 512) operating in a static mode, following the procedure described in a previous publication. ${ }^{9}$ The temperature was maintained constant to within $\pm 0.01 \mathrm{~K}$ by means of a recirculating bath equipped with a PID temperature controller (Julabo FP40-HP). For measuring the temperature a $100 \Omega$ platinum resistance thermometer (precision of $\pm 0.02 \mathrm{~K}$ and accuracy of $\pm 0.04 \mathrm{~K}$ ) was used. Its calibration was performed against a $100 \Omega$ platinum resistance Hart Scientific model 1502A.

The measured period of vibration $(\tau)$ of a $\mathrm{U}$ tube is related to the density $(\rho)$ according to: $\rho=A \tau^{2}+B$ where $A$ and $B$ are parameters that are a function of temperature. They were determined in the present work in the temperature range between (283 and 343) K. Three calibrating fluids were used: air, tridistilled water and two aqueous solutions of $\mathrm{NaCl}$ with accurate concentrations of approximately $1 \mathrm{~mol} \mathrm{~kg}^{-1}$ and $3 \mathrm{~mol} \mathrm{~kg}^{-1}$. These latter two fluids were chosen in order to cover a range of densities close to that of the ionic liquids studied. Measurements were performed in steps of $10 \mathrm{~K}$ and at least three independent values were obtained at each temperature. The precision of the density measurement is of the order $5 \times$ $10^{-4} \mathrm{~g} \mathrm{~cm}^{-3}$, the results are expected to be accurate to $10^{-3} \mathrm{~g} \mathrm{~cm}^{-3}$.

It is worth noting that for the case of viscous fluids, such as the ionic liquid measured here ( $\eta>100 \mathrm{mPa} \mathrm{s})$, a correction for the effect of viscosity should also be included ${ }^{8,9}$ Furthermore, due to the large effect of temperature on viscosity, this correction is only valid for narrow temperature ranges, close to room temperature. The effect of the viscosity on the density measurement was analyzed in order to validate the density measurements. In the 
case of $\left[\mathrm{C}_{4} \mathrm{C}_{1} \mathrm{Im}\right]\left[\mathrm{PF}_{6}\right]$, for which this effect will be greatest, the density was found to vary less than $0.1 \%$ and, therefore, the correction was considered to be negligible.

\section{Viscosity}

The viscosity was determined using a rheometer, Rheometrics Scientific SR200, that allows measurements from (293 to 393) $\mathrm{K}$ at atmospheric pressure and in a wide viscosity range (from 1 to $3000 \mathrm{mPa} \mathrm{s}$ ) depending on the geometry used. A Couette geometry (concentric cylinders) was chosen for this study. Temperature was maintained constant to $0.01 \mathrm{~K}$ by means of a recirculating bath similar to that used for the density measurements and was measured with the same accuracy. To avoid any water contamination of the sample during the measurement, the rheometer was placed inside a glove-box in an isolating atmosphere of purified and dried air. The rheometer was calibrated with an oil of known viscosity (viscosity standard oil from Brookfield, $95 \mathrm{mPa}$ s at $298 \mathrm{~K}$ ). Measurements were performed in steps of $10 \mathrm{~K}$ and at least three independent values were obtained at each temperature. A statistical analysis of our results indicates a precision in the viscosities of $0.2 \%$ and an expected overall uncertainty lower than $1 \%$.

\section{Low-pressure gas solubility}

The experimental method used for these gas solubility measurements is based on an isochoric saturation technique and has been described in previous publications. ${ }^{22-25,32-34}$ In this technique, a known quantity of gaseous solute is put in contact with a precisely determined quantity of degassed solvent at a constant temperature inside an accurately known volume. When thermodynamic equilibrium is attained, the pressure above the liquid solution is constant and is directly related to the solubility of the gas in the liquid.

The quantity of ionic liquid introduced in the equilibration cell, $V_{\text {liq }}$, is determined gravimetrically. The amount of solute present in the liquid solution, $n_{2}{ }^{\text {liq }}$ (subscript 2 stands for solute and subscript 1 stands for solvent), is calculated by the difference between two $p V T$ measurements: first when the gas is introduced in a calibrated bulb with volume $V_{\mathrm{GB}}$ and second after thermodynamic equilibrium is reached:

$$
n_{2}^{\mathrm{liq}}=\frac{p_{\mathrm{ini}} V_{\mathrm{GB}}}{\left[Z_{2}\left(p_{\mathrm{ini}}, T_{\mathrm{ini}}\right) R T_{\mathrm{ini}}\right]}-\frac{p_{\mathrm{eq}}\left(V_{\mathrm{tot}}-V_{\mathrm{liq}}\right)}{\left[Z_{2}\left(p_{\mathrm{eq}}, T_{\mathrm{eq}}\right) R T_{\mathrm{eq}}\right]}
$$

where $p_{\text {ini }}$ and $T_{\text {ini }}$ are the pressure and temperature in the first $p V T$ determination and $p_{\text {eq }}$ and $T_{\text {eq }}$ the pressure and temperature at the equilibrium. $V_{\text {tot }}$ is the total volume of the equilibration cell and $Z_{2}$ is the compressibility factor for the pure gas. The solubility can then be expressed in mole fraction:

$$
x_{2}=\frac{n_{2}^{\text {liq }}}{n_{1}^{\text {liq }}+n_{2}^{\text {liq }}}
$$

or as Henry's law constant:

$$
K_{\mathrm{H}}=\lim _{x_{2} \rightarrow 0} \frac{f_{2}\left(p, T, x_{2}\right)}{x_{2}} \cong \frac{\phi_{2}\left(p_{\mathrm{eq}}, T_{\mathrm{eq}}\right) p_{\mathrm{eq}}}{x_{2}}
$$

where $f_{2}$ is the fugacity of the solute and $\phi_{2}$ its fugacity coefficient.

\section{Conclusions}

This paper presents original gas solubility data in two ionic liquids based on the alkylsulfate anion- $\left[\mathrm{C}_{2} \mathrm{C}_{1} \mathrm{Im}\right]\left[\mathrm{C}_{2} \mathrm{SO}_{4}\right]$ and $\left[\mathrm{C}_{4} \mathrm{C}_{1} \mathrm{Im}\right]\left[\mathrm{C}_{8} \mathrm{SO}_{4}\right]$. The two ionic liquids are believed to be promising alternatives to traditional volatile organic solvents $\mathrm{s}^{3,8}$ and this work contributes to their physico-chemical characterization. The density and the viscosity of the two liquids studied were compared to those of other common ionic liquids. Although their viscosity is significantly higher than that of ionic liquids with the same cation but with other anions, like bis[(trifluoro)sulfonyl]imide or event hexafluorophosphate, it decreases dramatically with temperature and, above $350 \mathrm{~K}$, the viscosities of all the liquids are much closer. These high values of viscosity can be considered as a drawback for chemical or catalysis purposes, around room temperature, of this family of ionic liquids but can constitute an advantage for their use in other fields of application.

Of the two liquids studied in this work, $\left[\mathrm{C}_{4} \mathrm{C}_{1} \mathrm{Im}\right]\left[\mathrm{C}_{8} \mathrm{SO}_{4}\right]$ is capable of dissolving larger quantities of carbon dioxide and of hydrogen. When compared with other ionic liquids based on the same cation but with other anions, it dissolves lesser quantities of gases than the ionic liquid based on the bis[(trifluoro)sulfonyl]imide anion and approximately as much as the ionic liquid based on the hexafluorophosphate anion.

It was also observed that $\left[\mathrm{C}_{4} \mathrm{C}_{1} \mathrm{Im}\right]\left[\mathrm{C}_{8} \mathrm{SO}_{4}\right]$ is more viscous than other ionic liquids at temperatures close to the ambient. In particular, it is significantly more viscous than $\left[\mathrm{C}_{2} \mathrm{C}_{1} \mathrm{Im}\right]\left[\mathrm{C}_{2} \mathrm{SO}_{4}\right]$ and, at $300 \mathrm{~K}$, it exhibits a viscosity two times higher than that of $\left[\mathrm{C}_{4} \mathrm{C}_{1} \mathrm{Im}\right]\left[\mathrm{PF}_{6}\right] .\left[\mathrm{C}_{4} \mathrm{C}_{1} \mathrm{Im}\right]\left[\mathrm{C}_{8} \mathrm{SO}_{4}\right]$ is also much less dense than other ionic liquids based on the same cation, with densities not far from those of common organic solvents.

The properties of the two ionic liquids studied here can be explained in light of their molecular structures. ${ }^{35,36}$ It has been recently shown that the fluid structure in $\left[\mathrm{C}_{4} \mathrm{C}_{1} \mathrm{Im}\right]\left[\mathrm{C}_{8} \mathrm{SO}_{4}\right]$ is dominated by the apolar domains formed by aggregation of the alkyl chains of the cation and the anion. ${ }^{8}$ This argument can contribute to explain the higher values of viscosity of $\left[\mathrm{C}_{4} \mathrm{C}_{1} \mathrm{Im}\right]\left[\mathrm{C}_{8} \mathrm{SO}_{4}\right]$ when compared to $\left[\mathrm{C}_{2} \mathrm{C}_{1} \mathrm{Im}\right]\left[\mathrm{C}_{2} \mathrm{SO}_{4}\right]$.

We have shown before, using molecular simulation, that the solvation properties of the ionic liquids can be explained by their peculiar molecular characteristics. ${ }^{35}$ We have also shown that, when dissolved in $\left[\mathrm{C}_{4} \mathrm{C}_{1} \mathrm{Im}\right]\left[\mathrm{PF}_{6}\right]$, carbon dioxide interacts preferentially with the anion ${ }^{37}$ and is more probably located near the polar domains in the ionic liquid. The similar solubility of carbon dioxide in $\left[\mathrm{C}_{4} \mathrm{C}_{1} \mathrm{Im}\right]\left[\mathrm{C}_{8} \mathrm{SO}_{4}\right]$ and in $\left[\mathrm{C}_{4} \mathrm{C}_{1} \mathrm{Im}\right]\left[\mathrm{PF}_{6}\right]$, an ionic liquid with a much smaller anion, supports the idea that, although the anion in $\left[\mathrm{C}_{4} \mathrm{C}_{1} \mathrm{Im}\right]\left[\mathrm{C}_{8} \mathrm{SO}_{4}\right]$ is much larger than in $\left[\mathrm{C}_{4} \mathrm{C}_{1} \mathrm{Im}\right]\left[\mathrm{PF}_{6}\right]$, the electrostatic charge is concentrated in the $\mathrm{SO}_{4}$ group which will preferentially interact with carbon dioxide. The solubility of $\mathrm{CO}_{2}$ is then determined by this specific electrostatic interaction.

The analysis of the thermodynamic properties of solvation of $\mathrm{CO}_{2}$ in $\left[\mathrm{C}_{4} \mathrm{C}_{1} \mathrm{Im}\right]\left[\mathrm{PF}_{6}\right]$ (previously determined by Jacquemin et al. ${ }^{25}$ ) and in $\left[\mathrm{C}_{4} \mathrm{C}_{1} \mathrm{Im}\right]\left[\mathrm{C}_{8} \mathrm{SO}_{4}\right]$ (calculated in this work) does not permit to confirm the arguments developed above, which 
are related to structural features of the ionic liquids. It is observed that the enthalpy of solvation is slightly less negative in $\left[\mathrm{C}_{4} \mathrm{C}_{1} \mathrm{Im}\right]\left[\mathrm{C}_{8} \mathrm{SO}_{4}\right]$ than in $\left[\mathrm{C}_{4} \mathrm{C}_{1} \mathrm{Im}\right]\left[\mathrm{PF}_{6}\right]$ and because the Gibbs energy of solvation is similar for carbon dioxide in the two ionic liquids, the entropy of solvation is also slightly less negative for the solvation of $\mathrm{CO}_{2}$ in $\left[\mathrm{C}_{4} \mathrm{C}_{1} \mathrm{Im}\right]\left[\mathrm{C}_{8} \mathrm{SO}_{4}\right]$ than in $\left[\mathrm{C}_{4} \mathrm{C}_{1} \mathrm{Im}\right]\left[\mathrm{PF}_{6}\right]$.

These arguments surely deserve to be further developed by associating new experimental measurements of the solubility of other gases, both apolar, like oxygen or ethane, or having an important dipole moment, like for example nitrous oxide, with molecular simulations that provide an interpretation of the thermodynamic properties at the atomic scale.

\section{Acknowledgements}

The authors thank the group of P. Wasserscheid from ErlangenNurnberg University for supplying the IL samples. This study was part of a CNRS-DFG cooperation project between France and Germany and was also supported by the ADEME France (PhD grant of J.J.).

\section{References}

1 T. Welton, Green Chem., 2008, 10, 483.

2 D. J. Adams, P. J. Dyson and S. J. Tavener, Chemistry in Alternative Reaction Media, Wiley, Chichester, 2004.

3 P. Wasserscheid, R. van Hal and A. Bösmann, Green Chem., 2002, 4, 400-404.

4 J. D. Holbrey, W. M. Reichert, R. P. Swatloski, G. A. Broker, W. R. Pitner, K. R. Seddon and R. D. Rogers, Green Chem., 2002, 4, 407413.

5 C. Pretti, C. Chiappe, D. Pieraccini, M. Gregori, F. Abramo, G. Monni and L. Intorre, Green Chem., 2006, 8, 238-240.

6 N. Gathergood, M. T. Garcia and P. J. Scammells, Green Chem., 2004, 6, 166-175.

7 M. T. Garcia, N. Gathergood and P. J. Scammells, Green Chem., 2005, 7, 9-14.

8 M. J. Davila, S. Aparicio, R. Alcalde, B. Garcia and J. M. Leal, Green Chem., 2007, 9, 221-232.

9 J. Jacquemin, P. Husson, A. A. H. Padua and V. Majer, Green Chem., 2006, 8, 172-180.

10 J. Jacquemin, P. Husson, V. Majer and I. Cibulka, J. Chem. Eng. Data, 2007, 52, 2204-2211.

11 A. Fernandez, J. S. Torrecilla, J. Garcia and F. Rodriguez, J. Chem. Eng. Data, 2007, 52, 1979-1983.

12 R. Kato, M. Krummen and J. Gmehling, Fluid Phase Equilib., 2004, 224, 47-54

13 G. W. Meindersma, A. J. G. Podt and A. B. de Haan, Fluid Phase Equilib., 2006, 247, 158-168.
14 U. Domanska, Z. Zolek-Tryznowska and M. Krolikowski, J. Chem. Eng. Data, 2007, 52, 1872-1880.

15 A. B. Pereiro and A. Rodriguez, J. Chem. Eng. Data, 2007, 52, 600608.

16 E. Gomez, B. Gonzalez, N. Calvar, E. Tojo and A. Dominguez, J. Chem. Eng. Data, 2006, 51, 2096-2102.

17 N. Calvar, E. Gomez, B. Gonzalez and A. Dominguez, J. Chem. Eng. Data, 2007, 52, 2529-2535.

18 H. Rodriguez and J. F. Brennecke, J. Chem. Eng. Data, 2006, 51, $2145-2155$.

19 U. Domanska, A. Pobudkowska and A. Wisniewska, J. Solution Chem., 2006, 35, 311-334.

20 IUPAC Commission on Atomic Weights and Isotopic Abundances, Pure Appl. Chem., 1986, 58, 1677-1692.

21 J. H. Dymond and E. B. Smith, The Virial Coefficients of Pure Gases and Mixtures, Clarendon Press, Oxford, 1980.

22 G. Hong, J. Jacquemin, M. Deetlefs, C. Hardacre, P. Husson and M. F. Costa Gomes, Fluid Phase Equilib., 2007, 257, 2734.

23 J. Jacquemin, P. Husson, V. Majer and M. F. Costa Gomes, J. Solution Chem., 2007, 36, 967-979.

24 J. Jacquemin, M. F. Costa Gomes, P. Husson and V. Majer, J. Chem. Thermodyn., 2006, 38, 490-502.

25 J. Jacquemin, P. Husson, V. Majer and M. F. Costa Gomes, Fluid Phase Equilib., 2006, 240, 87-95.

26 J. Kumelan, A. P.-S. Kamps, D. Tuma and G. Maurer, J. Chem. Eng. Data, 2006, 51, 11-14.

27 J. H. Hildebrand, J. M. Prausnitz and R. L. Scott, Regular and Related Solutions, Van Nostrand Reinhold, New York, 1970.

28 J. Kumelan, A. P.-S. Kamps, D. Tuma and G. Maurer, Fluid Phase Equilib., 2007, 260, 3-8.

29 J. Kumelan, A. P.-S. Kamps, D. Tuma and G. Maurer, J. Chem. Eng. Data, 2006, 51, 1364-1367.

30 W. Xu, L.-M. Wang, R. A. Nieman and C. A. Angell, J. Phys. Chem. $B, 2003,107,11749-11756$.

31 C. Villagran, M. Deetlefs, W. R. Pitner and C. Hardacre, Anal. Chem., 2004, 76, 2118-2123.

32 P. Borg-Husson, V. Majer and M. F. Costa Gomes, J. Chem. Eng. Data, 2003, 48, 480-485.

33 M. F. Costa Gomes, P. Husson, J. Jacquemin and V. Majer, ACS Symp. Series Ionic Liquids III: Fundamentals, Progress, Challenges, and Opportunities, ch. 16, ed. R. D. Rogers and K. R. Seddon, American Chemical Society Publications, Washington D.C., 2005.

34 M. F. Costa Gomes, J. Chem. Eng. Data, 2007, 52, 472475.

35 J. N. Canongia Lopes, M. F. Costa Gomes and A. A. H. Padua, J. Phys. Chem. B, 2006, 110, 16816-16818.

36 A. A. H. Padua, M. F. Costa Gomes and J. N. A. Canongia Lopes, Acc. Chem. Res., 2007, 40, 1087-1096.

37 J. Deschamps, M. F. Costa Gomes and A. A. H. Pádua, ChemPhys Chem, 2004, 5, 1049-1052.

38 J. Jacquemin, P. Ge, P. Nancarrow, D. Rooney, M. F. Costa Gomes, A. A. H. Padua and C. Hardacre, J. Chem. Eng. Data, 2008, 53, 716-726. 